DOI https://doi.org/10.36059/978-966-397-154-4/120-134

\title{
WATER AND ENERGY SAVING TECHNOLOGIES OF TILLAGE IN THE CONDITIONS OF SOUTHERN ARID AND DRY STEPPE OF UKRAINE
}

\section{Maliarchuk M. P.}

\section{INTRODUCTION}

Basic tillage is one of the most important agrotechnical measures in crop cultivation technologies, which significantly affects the agrophysical properties, water and nutrient regimes of soil and forms the directions of soil-forming processes.

Tillage technologies influence differently on the individual layers of arable and sub-arable horizons. Unlike organic and mineral fertilizers, mechanic tillage does not add substance or energy to the soil, but causes significant changes in the ratio of the solid, liquid and gaseous phases of the soil system. It affects a variety of chemical, physico-chemical and biological processes, accelerating or suspending the rate of synthesis or decomposition of organic matter. Basic tillage plays role of the main factor in creating favorable physical conditions for soil fertility formation and remains one of the most important environmentally friendly measures for control of weeds, pests and diseases of crops.

Ways and depth of basic tillage for crops and crop rotation systems, which are formed in accordance with ecological and technological grouping of lands and specialization of farms, should be directed to the reduction of anthropogenic energy consumption, reduction of the tempo of mineralization of organic matter and prevention of the degradation processes.

At the present stage of development of agriculture, theoretical substantiation has been made with the subsequent practical application of two methods of basic tillage: plow and plowless, which can be deep, shallow or surface. Besides, each of the tillage methods has a significant number of techniques. So, the plowless tillage can be subsurface, chisel, disk; plow tillage - ordinary, double-layer, deep-plowing and cultural plowing. However, the whole list of techniques comes down to two fundamentally different ways of the plow and plowless, because subsurface, chisel, minimal, zero, conservation ones are varieties of plowless tillage, which is such a tillage, when the arable layer does not rotate. 
Plow tillage has got a priority in agricultural production till nowadays. It is based on modern substantiation that the fertility of arable soil profile is differentiated by the layers: the top layer is more fertile than the bottom one. Agricultural systems in their development have long been based on the use of plows with shelves of various modifications. However, the leading scientists in the field of agriculture do not consider such tillage as having no alternative. The basic requirements for plowing - to create in the soil the conditions, which are necessary for the development of crops; however, it should be carried out as rarely as possible, not more than once or twice per rotation, depending on the number of fields in rotation, since it requires significant costs, whatever perfect tools are used to perform it. Besides, plowing involves some destruction of the soil structure by the action of the plow working bodies and the pressure of the tractor's weight ${ }^{1}$. In the history of the development of views on soil tillage, the advantages of shallow and surface cultivation have occasionally been noted.

The researchers of the Odesa Scientific Station of NAAS, located in the Odesa region, consider that it is necessary to significantly increase the area of non-plowing tillage in the perspective, as it does not reduce the yield of crops, but also protects the soil from erosion and over-compaction, slows down the process of mineralization of humus, increases the productivity of labor, resolves the problem of weed control through the use of highly efficient herbicides, enhances the culture of agriculture, and saves fuel and lubricants ${ }^{2}$.

In the south of Ukraine, plowless tillage with the use of soil-cultivating tools with chisel-type working bodies, as well as the use of seeders for sowing into the non-processed soil, deserves attention. The advantage of plowless tillage for winter wheat, barley and rye is approved by the data of the Askania State Agricultural Research Station of the Institute of Irrigated Agriculture of NAAS ${ }^{3}$.

Plowless tillage is more and more widespread in production every year, and its effect is being determined, first of all, by the crop yield, increased labor productivity and reduced non-renewable energy expenditures.

During the recent years, the NAAS scientific institutions functioning in the Steppe zone have accumulated significant experimental material on the

${ }^{1}$ Гудзь В. П., Примак І. Д. та ін.Адаптивні системи землеробства: підручник. К.: Центр учбової літератури, 2007. 334 с. $125 \mathrm{c}$.

Щербак И. Е. Почвозащитная обработка полей в южных районах. М.: Колос, 1974.

${ }^{3}$ Малярчук М. П. Вплив грунтозахисних систем обробітку в сівозміні на родючість грунту, забур'яненість посівів та продуктивність сільськогосподарських культур. Зроиуване землеробство: міжвідомчий тематичний науковий збірник. 1992. Вип. 37. C. 13-19. 
use of a plowless method of basic tillage, while scientific data on its impact on the soil are contradictory and indicate not only a positive but also a negative impact on physical, chemical, biological and phytosanitary condition. On the one hand, this method of tillage slightly improves the water regime of the soil and its erosion resistance, and on the other, an increase in the weediness of crops and the number of diseases and pests is observed ${ }^{4}$.

Considering that the soil cover of the zone is represented by ordinary and southern chernozem, agrophysical properties of which are optimal for most crops even in the equilibrium, including root-crops, as well as dark-chestnut of varying degrees of alkalination, meadow-chestnut and meadowchernozem soils, which are glei, are confined to the closed wetlands, agrophysical properties of which are marginal for crops, the only approach to the choice of method and depth of basic tillage cannot be applied ${ }^{5}$.

The basic tillage of each soil in the Steppe zone should be directed to the accumulation and preservation of soil moisture, creation of favorable conditions of mineral nutrition of plants, preservation and increase of soil fertility and improvement of phytosanitary and ameliorative state in agrocenoses $^{6,7}$.

In the conditions of Southern arid and dry-steppe soil ecological zones of southern Ukraine, moisture is the main factor that limits the obtaining of high yields. Therefore, the accumulation and conservation of moisture in the soil and its economical use is a priority of modern agriculture. The main role in this belongs to the basic and pre-sowing tillage.

Tillage obtained particularly important value in the soil moisture accumulation in recent decades, due to the increasing aridity of the climate in the region. Over the last forty years, the average annual temperature in Southern Steppe has increased by $2^{\circ} \mathrm{C}$, including in March and April by 1.3 and $1.6^{\circ} \mathrm{C}$, and in September and October by $2.9,1.8^{\circ} \mathrm{C}$, respectively ${ }^{8}$.

\footnotetext{
${ }^{4}$ Меліорація грунтів (систематика, перспективи, інновації): колективна монографія; за ред. С.А. Балюка, І.М. Ромащенка, Р.С. Трускавецького. Херсон: Грінь Д.С., 2015. 668 с.

5 Малярчук М. П. Система обробітку грунту. Наукові основи охорони та раціонального використання зрошуваних земель України. Київ: Аграрна наука, 2009. C. 299-313.

${ }^{6}$ Камінський В. Ф., Сайко В. Ф. Стратегія розвитку адаптивних систем землеробства і агротехнологій в Україні. Адаптивні системи землеробства і сучасні агротехнології основа раціонального землекористування, збереження і відтворення родючості грунтів. К.: ВП «Едельвейс», 2013. С. 5-24.

7 Гордієнко В. П., Грабак Н. Х. Малієнко А. М. Прогресивні системи обробітку грунту; за ред. В.П. Гордієнка. Сімферополь, 1998. 272 с.

${ }_{8}$ Kovalenko A. Increasing aridity climate of southern steppe of Ukraine. Its effects and remedies, 3rd UNCCD Scicntific Conference, 9-12 March 2015, Cancun. Mexico: Book of Abstracts, 2015. P. 293-294.
} 
The annual rainfall during this period decreased slightly, but not as significantly as in the spring and autumn period. Thus, in March, September and October their number decreased by two times ${ }^{9}$. This complicates both basic tillage and pre-sowing tillage conduction.

In the autumn during the last years, the soil is very dry and not it is not always possible to conduct qualitative tillage. The cultivated soil under such conditions is very clayy, crumbles badly, the post-harvest residues and weeds are not incorporated qualitatively. This often causes the delay of tillage time to December and even January. Under such conditions, the period from plowing to the beginning of spring-field work is greatly reduced, which does not allow the soil to create the bumpy structure necessary for the sowing of spring crops in the short term. In addition, the soil does not have time to compact and remains loose, which leads to the formation of deep tracks on the passes of tractors and does not create sufficient contact with the seeds of spring crops during sowing.

The requirements of modern Steppe agriculture are the most fully compliant with the system of differentiated tillage methods. It should be adapted to the zonal conditions, dynamic, energy- and moisture-saving and environmental protection, to take into account the phytosanitary conditions of the fields and the genetically determined potential of crop productivity and to ensure the effective soil fertility.

Deep $(25-30 \mathrm{~cm})$ tillage is of particular importance on heavy by the mechanical composition, alkaline, structureless and compaction-prone soils. Row crops (root-crops, corn), perennial herbs and legumes respond positively to deep loosening. The need for deep tillage is also determined by the need to eliminate root weeds, incorporate organic fertilizers and residues that remain on the field. The duration of its effects in rotation increases on well-humus chernozems and decreases with the use of heavy machinery.

Shallow $(8-16 \mathrm{~cm})$ and surface $(6-8 \mathrm{~cm})$ tillage is advisable to carry out for winter wheat, spring cereals on the cultivated flat areas, as well as soils of light and medium granulometric composition that are well saturated with carbonates, chernozems with high (more than 40\%) content of waterresistant aggregates. The efficiency of minimum tillage increases with shallow groundwater layer $(1-2.5 \mathrm{~m})$ and the presence of perennial legumes in the crop rotation.

Zero tillage is promising under the sufficient humidification on fertile light soils (humus content of more than $4 \%$ ) after corn, sunflower, sorghum,

${ }^{9}$ Вожегова Р. А., Коваленко А. М., Малярчук М. П. та ін. Формування систем обробітку грунту в короткоротаційних сівозмінах: науково-методичні рекомендації. Херсон: ВЦ І33, 2015. 18 с. 
beets under early spring, at winter wheat cultivation after non-fallow forecrops, as well as post-harvest and post-mowing crops. Direct sowing drills work qualitatively on shallow and surface-tilled agricultural backgrounds.

Almost all of these systems, in addition to sowing in pre-tilled soil, must be subjected to stubbling before basic tillage.

Timely stubbling eases basic tillage and improves the quality of its conduction, prevents the growth of weeds and drying of the lower soil layers, improves the living conditions for microorganisms and accelerates the decomposition of plant residues.

Stubbling contributes to the destruction of the seeds fall, causing the death of stem pests and pathogens of plants whose life cycle is related to the topsoil or stubble (root rot, rust, powdery mildew).

In the zone of manifestation of wind and water erosion good results are provided by heavy universal cultivators manufactured by TOV Krasnyansk SP Agromash of the types KV-3.0 N, KV-4.0 N, KV-6.0 N, and disc-chisel harrows BDC-5, BDC-6, BDC-7. They provide complete cutting of perennial weeds and leave on the surface $60-70 \%$ of post-harvest residues that mulch the soil and in 3-5 times reduce the erosion action of rain and prevent crust formation. This reduces the risk of soil erosion and loss of water from runoff.

Depth and number of stubbling depends on weediness and mass of postharvest residues. In the case of weediness with mainly annual weeds, disc plowing on the depth of $6-8 \mathrm{~cm}$ is used. In the fields where there is a lot of sow thistle and other root-weeds, a two-time multi-depth stubbling is effective: first on the depth of 6-8 cm, the second on a depth of $10-12 \mathrm{~cm}$ with disk tools BDLP-8, BDLP-4. Owing to the small width of cut of working bodies, the optimum angle of breaking and equipment with rollers they provide high-quality cutting of perennials and loosening of the soil surface. After the stubble forecrops, when all the straw is left in the field, and after the tillage of coarsestem (corn, sorghum, sunflower) crops whose post-harvest residues requires long time to be mineralized in the soil, the quality of stubbling is better at the use of heavy disk harrows BDVP-4.2-0.1, BDVP-3.0-0.1 equipped with the working bodies of disk and chisel type and rollers. At the use of these combined tillage machines for one pass of the aggregate, the qualitative preparation of the soil for sowing of winter cereals is ensured.

\section{Basic tillage of plowland}

In the enterprises of the irrigated zone of Ukraine, which specialize in corn cultivation, soybean and sunflower for industrial processing in short 
crop rotations using all the by-products (leaf-stem mass) for fertilizer, plowing is currently one of the most common methods of tillage. Preference should be given to high-clearance reversible plows with variable cut widths that provide smooth plowing on a depth of 20 to $30 \mathrm{~cm}$ without primary grinding of plant residues. Owing to the smoothed surface on the background of smooth plowing, technological operations related to soil preparation and sowing in the spring are performed better than usual.

The advantage of subsurface tillage in comparison to plowing can be observed in the conservation of moisture during the years with low rainfall during autumn and winter and with an active wind regime in the spring. It is especially effective in improving the physicochemical properties of the subsurface layer of medium- and highly-washed out soils, at the cultivation of solonetz. It is suitable for the long-term use in field crop rotations.

One of the types of subsurface tillage is loosening of soil to a depth of 12 to $20 \mathrm{~cm}$ by flat-cutting tools of different types (KR-4.5; AKS-5.4; KPS-5), at the use of which more than a half of the post-harvest residues remains on the soil surface. High efficiency of plowless tillage is evident on chernozems with light and medium mechanical composition and on the fields that are exposed to wind erosion.

It is impractical to use the tools with flat-cutters after corn for grain, sorghum crops and sunflower, which are discharged under spring cereals, as well as on the compacted and dry soils. In this case, there is an unsatisfactory crumbling of the chunk, accumulation of dust on the surface of the soil, decrease in the water permeability of the soil.

The rapid development of economical agrotechnology, due to the economic and energy factors and limited labor resources, has led to widespread use in the production conditions of shallow tillage, which is proved to be the most suitable for cultivation of early cereals after row crops (corn, sunflower, sugar-beet) on the well-cultivated fields.

At the same time, as the results of scientific research and practical experience testify, its effectiveness is reduced on saline chestnut soils and heavy by the mechanical composition chernozem soils of low humus content, as well as on the slopes of more than $2^{\circ} \mathrm{C}$. The shallowly loosened eroded soil is quickly compacted and overcrusted, but at the same time it is not able to accumulate moisture from rainfall and can be washed away with water from the bottom of the furrow to the entire depth of cultivation ${ }^{10}$.

\footnotetext{
${ }^{10}$ Вожегова Р. А., Коваленко А. М. Зміни клімату в південному регіоні та напрями адаптації землеробства до них. Посібник украӥнського хлібороба "Адаптивне землеробство». Київ: ТОВ «АКАДЕМПРЕС», 2013. Том 1. С. 189-190.
} 
At the shallow tillage, the phytosanitary condition of the crops is deteriorating, the volume of pesticide use is increasing, there is a problem of economic feasibility and environmental safety of production.

Shallow tillage is often the reason for the unstable water regime of the soil. The density and hardness of the underlying surface layer significantly limits the moisture accumulation here in the autumn and winter. According to the perennial data of the Institute of Grain Farming, the use of shallow disc tillage for the row crops leads to the accumulation of less productive moisture in the deep layers of the soil and to a decrease in corn yield by 0.44 , sunflower by 0.28 tha in comparison to the chisel loosening.

A persistent tendency to the decrease of the yield of early spring cereals with shallow winter tillage is observed in the fields with a large amount (more than $5 \mathrm{t} / \mathrm{ha}$ ) of uncrispy post-harvest residues of the forecrop. On this agrophone, the quality of pre-sowing cultivation and sowing with drills SZ-3.6 A, SZ-5.4 equipped with disk coulters is significantly deteriorated. The risks associated with the wrapping of all the by-products of the crop directly into the topsoil are partially offset by the use of special shredders of the leaf-stem mass and of the Amazon-Horsch-Agro-Union type sowing and tillage complexes. According to the data of the Institute of Irrigated Agriculture of NAAS, the influence of the basic tillage system in Southern Steppe on moisture accumulation in the autumn and winter has slightly changed in recent years. It was previously recognized that the greatest amount of moisture during this period in southern region accumulates at deep plowing. But this is not always the case now. Studies of different tillage of winter wheat forecrops indicate that, as before, the advantage of moisture accumulation in the autumn period remains in deep plowing.

However, this advantage is much less than 20-25 years ago. In addition, during the autumn and winter period, productive moisture reserves are leveled for all tillage options. With regard to basic tillage under the spring crops, there were no significant changes in soil moisture accumulation detected in different ways of basic tillage under the influence of climate change. As before, the reserves of productive moisture in the meter layer of soil are almost independent on the way and depth of the basic tillage.

\section{Tillage for the spring crops}

In the Steppe zone, the restoration of moisture reserves is mainly through the fall-winter precipitation. The insufficient level of their assimilation (30$40 \%$ ) is largely caused by poor basic tillage of the soil, in particular, its excessive lumpiness, which increases the processes of evaporation, blowing out and freezing of water. The likelihood of the formation of a lumpy surface 
is significantly increased by conducting a deep winter tillage without primarily stubbling, especially in the fields with heavy machinery and in drought conditions ${ }^{11}$.

Zero tillage. For the last time, so-called zero tillage, or sowing into nontilled soil, has become widespread. It provides a radical solution to the problem of conservation of energy resources and soil protection through the introduction of zero crop cultivation technologies in agrarian production, based on the complete disawowal of mechanical tillage with the exception of the operation of seed bed preparation simultaneously with sowing by using special drills (Great Plains, Kinze, ATD-9.35, Sirius-10).

The studies of the Steppe scientific institutions testify that the efficiency of zero tillage is determined, first of all, by the soil and climatic conditions, the duration of its application and the tolerance of the crops. Its main advantages include high anti-erosion resistance and minimal fuel and labor costs, the drawbacks are significant dependence on chemicals and prices for the means of production.

On the background of the conventional tillage system, a one-time sowing in the previously untilled soil slightly changes the water-physical properties of the arable layer, however, the range of indicators is within the limits of biological optima and does not cause a negative reaction of crops. The possibility of chernozem to restore its optimal parameters is significantly diminished in cases of prolonged application of zero tillage and when rainfall does not ensure normal plant development.

In severely dry years on heavy by mechanical composition soils (physical clay content of more than $45 \%$ ), untilled soil is over-compacted in May-June to the critical level, capiillary ruture occurs later and at the smaller absolute value than on the plowland that leads to the significant increase (by $12-41 \mathrm{~mm}$ ) of unproductive losses of soil moisture, resulting in the difficulties of obtaining good seedlings of late spring crops in hot weather on zero dehydrated agrophones.

The risks associated with direct sowing of crops are increased in the presence of perennial weeds and on dark-chestnut and chestnut soils of the dry and very dry Steppe under the leaving a large number of rough plant residues in the field.

Our studies conducted at the Askania Research Station of the Institute of Irrigated Agriculture testify that the use of zero tillage for spring crops

11 Тимошенко Г. 3., Коваленко А. М., Новохижній М. В. Вплив різних способів основного обробітку грунту на урожайність ячменю ярого. Зрошуване землеробство: міжвідомчий тематичний науковий збірник. Херсон: Грінь Д.С., 2015. Вип. 64. C. 114-116. 
increases the bulk density of soil in the layer of $0-40 \mathrm{~cm}$ by $0.08-0.17 \mathrm{~g} / \mathrm{cm}^{3}$, and on winter crops by $0.04-0.11 \mathrm{~g} / \mathrm{cm}^{3}$ in comparison to deep tillage. Soil permeability is reduced by $17-23 \%$.

The yields of spring crops of the ordinary row sowing (spring wheat, peas, mustard) are reduced by $15.5-31.7 \%$ in comparison to deep tillage and by $11.1-27.7 \%$ in comparison to shallow tillage. The yield of row crops (sorghum) decreased by $51.9 \%$ in comparison to deep tillage and by $44.5 \%$ in comparison to shallow tillage.

Soil slotting. Slotting through the deep (up to $60 \mathrm{~cm}$ ) soil cutting is used mainly on slope lands to regulate the flow of meltwater and enhance the accumulation of precipitation. On dark-chestnut and chestnut soils in the area of irrigation systems of Ukraine, slotting significantly improves the use of irrigation water and moisture supply of field crops, increases the productivity of irrigated crop rotation by dry matter output by $0.5-0.7 \mathrm{t} / \mathrm{ha}$, or $17-20 \%$. Slotting is effective on crops of winter and perennial herbs, soils of heavy mechanical composition with low humus content, which are prone to fast over-compaction. It is carried out by deep-loosening machines CG 40, CG 40-01, CG 40-02, CG 5.5 produced by TOV «Krasnyansk SP» Agromash».

On the eroded lands, slotting of perennial herbs is particularly effective, where the soil is most compacted and plants often lack moisture and oxygen. The agricultural measure is carried out in the fields occupied by the herbs of the second and third years of use before freezing of the soil.

Boundary slotting in the system of early fallow has a priority after sunflower and corn that have been grown at the ridges. Here, it provides an additional accumulation of $250-300 \mathrm{~m}^{3} /$ ha of melted water, greater depth of soil wetting and, as a result, increased winter wheat yields in the area of slotting.

Soil mulching. The main task of mulching tillage is to create a soilprotective surface from the plant residues of the previous or intermediate crop to protect the soil from deflation and washing out, additional accumulation of snow, reduction of water runoff and unproductive evaporation. The protective and moisture-saving effect of the agrophone depends on the amount, physical properties, orientation, aerodynamic rigidity and height of the plant residues, as well as the power, porosity and uniformity of the mulching layer. Significantly reduces erosion and moisture loss evenly covering of $60-80 \%$ of the field area with the crop residues of the forecrop, which, in terms of grain equivalent of cereals, is about 2-4 t/ha.

Soil mulching with post-harvest residues in the Steppe plays a particularly important role in the cultivation of row crops and keeping pure 
fallow, the surface of which is the least protected from the effects of destructive factors. It is possible to halt the erosion and degradation of the chernozems on the plains and slopes by transition from the classical fallows to the early ones, since the latter are completely protected from blowing in the winter and spring, and the flow of meltwater here does not cause significant soil erosion.

The resistance of early fallow to the erosion of summer rainfall increases with the presence on the surface of more than $2.5 \mathrm{t} / \mathrm{ha}$ of plant substrate, the conservation of which is achieved by transferring the terms of basic tillage to May and carrying it with a plowless tools at a depth of loosening $12-16 \mathrm{~cm}$, reducing the number of technological operations, replacement of cultivations with harrowing, application of herbicides. For fallow mulching it is advisable to use coarse post-harvest residues of corn, sorghum, Sudanese grass, which are partially incorporated, mixed with the topsoil and have a long period of rotting. In this case, the surface becomes rough and absorbs water better, at the same time, it diminishes the processes of crust formation, siltation and blocking of pores.

At the cultivation of row crops, which in the Steppe are mainly placed in after stubble forecrops, a high degree of surface coverage with post-harvest residues in the cold season ensures winter tillage of the soil.

For the time of sowing corn and sunflower by using the elements of conventional technology (moisture covering, two pre-sowing cultivations) the number of post-harvest residues is reduced to the critical mark of 80$100 \mathrm{pcs} / \mathrm{m}^{2}$ (0.7-0.9 t/ha), and projectivity does not exceed $20-25 \%$. Such agrophone loses its anti-erosion ability even when the average intensity of the rain falls by a layer of $25-30 \mathrm{~mm}$ and the wind speed is $12-15 \mathrm{~m} / \mathrm{min}$.

The improvement of moisture-saving and soil-protective efficiency of mulching at the cultivation of row crops is mainly achieved by leaving all or part of the by-products within the field, reducing the number of mechanical tillage and using technical means that incorporate less of the crop residues in the soil: combined aggregates and drills for sowing in previously non-tilled soil.

Pre-sowing tillage. Creation of reliable anti-erosion and moisture-saving agrophone during the pre-sowing period is achieved by minimizing tillage due to the exclusion of individual operations, reducing the depth of loosening, combination of technological operations, the use of wide-cut and combined aggregates.

On the leveled fields after stubble forecrops, which were processed with heavy disk harrows in the autumn, it is not advisable to carry out early spring harrowing. In the cultivation of early spring cereals and legumes in such areas, it is desirable to use cultivators K-4.3, K-7.3 K-9.3, K-11, which 
in the one pass carries out the preparation of the seed bed, mulching, leveling and compaction of the cultivated layer of the soil.

On the cloddy plowland, where the convection-diffuse process of moisture loss prevails, it is covered in the first days of spring-field work by heavy tooth or wide-cut combined aggregates AK-6, AK-7, which in the one pass level the surface of the soil, perform loosening to $4-16 \mathrm{~cm}$ depth, and compacts the treated layer.

The studies of the Steppe scientific institutions testify that, due to the high crop cultivation and improved basic tillage on chernozem under corn and sunflower, it is possible to come to one pre-sowing cultivation of the soil. In addition to the economic cost, it allows you to retain moisture and obtain good seedlings.

Extremely deep tillage in the spring under spring crops increases the porosity of the soil, which enhances its drying, especially in hot windy weather. Therefore, the depth of pre-sowing cultivation must in all cases correspond to the depth of seed incorporation. Violation of this agrotechnical requirement leads to the placement of seeds in the semi-dry layer of soil and thinning of the seedlings.

\section{Tillage for winter crops}

Classical fallow. Фe epy proper preparation, classical fallow is equaled to irrigation, guarantees 6-8 t/ha of high-quality winter wheat grain and has a positive effect on the growth and development of subsequent crops. However, it remains the most vulnerable field of crop rotation, where it is extremely difficult to slow down soil erosion.

Among the approved tools for soil-protective basic tillage of classical fallow, the best ones are heavy chisel cultivators, which provide high antierosion efficiency and high quality of fertilizers incorporation.

The introduction of earlyfallow is a radical measure to counteract the destruction and degradation of soils. By the amount of accumulated moisture in the cold season, the untreated agrophone (early fallow) does not cede to classical fallow in autumn, but is not susceptible to erosion even at critical wind and runoff speeds. With increased buffer, holding and clogging capacity, the soil washes out here were 1.6-4.1 t/ha, which is 5-11 times less than under plowing $(18.3 \mathrm{t} / \mathrm{ha})$.

The technology of basic tillage of early fallow after sunflower, corn, Sudanese grass, sorghum is based on the complete exclusion of autumn tillage, background stubbling at the beginning of spring field work and the subsequent (3-4 weeks) loosening of the soil by heavy chisel cultivators to a depth of 16-18 cm depending on the relief, the weather comditions, the mass 
of plant residues and the weediness of the field. With a high load capacity, the early fallow preparation process scheme may include late-autumn soil slotting by the band scheme of 2x140 cm every 4-6 $\mathrm{m}^{12}$.

Care for classical fallow. It is based on the principles of agrienvironment and economic feasibility, with priority being given in the first half of the summer to the measures directed to clearing the fallow from weeds, and in the second - to focusing on the prevention of the excessive loss of soil moisture.

In all cases, the first shallow $(8-10 \mathrm{~cm})$ cultivation of the fallow field is less effective than the deep one $(12-14 \mathrm{~cm})$, at which perennial weeds are destroyed, no compacted layer is created, the soil resists erosion better and absorbs moisture well. Among the tested soil tillage tools, when performing the first deep cultivation on the plowless backgrounds, the advantageous are anti-erosion cultivators KEE-3.8, KPE-6H and combined aggregates of the type KP-4.5, equipped with flat-cutting paws and rotary disc consoles, on the plowlands - modified fallow cultivators KPS-4, the construction of which limits the vibrations of the risers in the horizontal plane and provides loosening of the soil to a predetermined depth and qualitative cutting of weeds.

For the surface tillage of fallow fields the cultivators equipped with working bodies of flat-cutting type, which prevent the excessive destruction of mulch and mixing of dry and moist soil layers, save moisture at the depth of seed wrapping, are used. Flexi-Coyle ZBR-24 spring and tooth harrows are effective on the plowless backgrounds. To avoid over-compaction of the arable layer, especially in the spring, the wide-cut aggregates with radially or twin tires with low specific pressure on the soil should be used for the care of the fallow field.

Green fallow. Taking into account the differences of the fallow crops, the specificity of the Steppe relief and climate, the system of tillage of the green fallow is subordinated to the solution of two main tasks: creation of an erosion-resistant surface of the field in the post-harvest period and prerequisites for the guaranteed obtaining of full-value seedlings of winter crops.

The main importance in the preparation of the green fallow (after winter, grain mixtures for green manure) has timeliness, consistency and regularity of technological operations: immediate stubbling of stubble with disc

\footnotetext{
${ }^{12}$ Малярчук М. П., Вожегова Р. А., Марковська О. С. Формування систем основного обробітку грунту в агробіоценозах на меліорованих землях південної посушливої та сухо степової грунтово-екологічних підзон України: навчальний посібник. Херсон: Айлант, 2012. $180 \mathrm{c}$.
} 
harrows on $8-10 \mathrm{~cm}$, tillage with combined aggregates of the type KR-4.5, KRG-5, AKS-5.4 on 10-12 cm, loosening of the soil with fallow cultivators on the depth of seed wrapping.

Perennial herbs. Preparation of the field for winter wheat after perennial herbs on the basis of moldboard plowing in dry years leads to excessive lumpiness of soil, which causes significant losses of moisture, inhibition of microbiological processes, deterioration of the quality of sowing operations.

Resource- and water-saving technology of soil tillage after perennial herbs involves loosening with heavy disc harrows on the depth of 10-12 cm followed (with a gap of 2-3 days) by shallow $(14-16 \mathrm{~cm}$ ) one. At the observation of agrotechnical standards such a scheme of tillage excludes the possibility of regrowth of perennial herbs and guarantees conservation of residual moisture and its accumulation from summer rainfall.

Pea. The bulk density of arable soil layer at the time of harvesting of the leguminous crop mostly exceeds the optimally permissible index of $1.30 \mathrm{~g} / \mathrm{cm} 3$ that leaves out the possibility of qualitative plowing of the field. Therefore, after peas, in the presence of sufficient moisture reserves, the soil is cultivated by light disc harrows of the BDLP-8 and BDLP-10 type. Subsequent formation of optimal agro-physical parameters of the sowing layer, weed and seed fall destruction is achieved by the conduction of cultivations with combined multioperative cultivators with rollers.

At the placement of winter crops after row crops of corn, sunflower, it is necessary to perform mulching tillage with heavy disj harrows on the day of harvesting, which includes grinding of the post-harvest residues and partially incorporation of them with heavy disc harrows and pre-sowing cultivation on the depth of seed wrapping.

\section{CONCLUSIONS}

In Southern arid and Dry Steppe soil-ecological zones of Ukraine on the plain-lands of first technological group it is advisable to introduce grainfallow-row systems of agriculture with corresponding structure of sown areas and crop rotations, and implement systems of differentiated soil tillage at which surface and shallow disk tillage under cereal crops during the rotation is interchanged with deep plowing, chisel loosening or slotting once per the rotation of 4-5-foeld crop rotations.

\section{SUMMARY}

Experimental materials on the determination of the use efficiency of different ways and depths of basic tillage in the arid conditions of Southern 
arid and dry Steppe soil-ecological zones of Ukraine at the cultivation of winter wheat after different forecrops are presented.

Methods: field, analytical, estimation and comparison, mathermatical statistics. Results. Experimental studies testify that for the years of the study winter wheat yields ranged from 2.70 to 4.90 t/ha depending on the studied factors. Comparing the crop yields by the ways of tillage, certain dependence was found. Thus, at plowing on the depth of $14-16 \mathrm{~cm}$ in a system of differentiated plowing tillage without fertilizer, the yield was 3.15 $\mathrm{t} / \mathrm{ha}$, and at the chisel tillage on the same depth in the system of plowless loosening $-3.01 \mathrm{t} / \mathrm{ha}$ or by $4.6 \%$ lower. Shallow disk loosening under the long-term application in the crop rotation resulted in a decrease in yields by $14.3 \%$ and $11.5 \%$, respectively, in comparison to differententiated systems. The most energy-efficient variant is an experiment with mineral fertilizers application. Conclusions. On the dark-chestnut middle-loamy soils of the South of Ukraine in the crop rotations it is advisable to apply systems of differentiated tillage when surface and shallow disk tillage for winter wheat and barley during the rotation is changed by deep plowing or chisel loosening.

\section{REFERENCES}

1. Гудзь В. П., Примак І. Д. та ін. Адаптивні системи землеробства: підручник. К.: Центр учбової літератури, 2007. 334 с.

2. Щербак И. Е. Почвозащитная обработка полей в южных районах. М.: Колос, 1974. 125 с.

3. Малярчук М. П. Вплив грунтозахисних систем обробітку в сівозміні на родючість грунту, забур'яненість посівів та продуктивність сільськогосподарських культур. Зрошуване землеробство: міжвідомчий тематичний науковий збірник. 1992. Вип. 37. С. 13-19.

4. Меліорація грунтів (систематика, перспективи, інновації): колективна монографія; за ред. С.А. Балюка, І.М. Ромащенка, Р.С. Трускавецького. Херсон: Грінь Д.С., 2015. 668 с.

5. Малярчук М. П. Система обробітку грунту. Наукові основи охорони та раціонального використання зрошуваних земель України. Київ: Аграрна наука, 2009. С. 299-313.

6. Камінський В. Ф., Сайко В. Ф. Стратегія розвитку адаптивних систем землеробства і агротехнологій в Україні. Адаптивні системи землеробства і сучасні агротехнології - основа раціонального землекористування, збереження і відтворення родючості грунтів. К.: ВП «Едельвейс», 2013. С. 5-24. 
7. Гордієнко В. П., Грабак Н. Х. Малієнко А. М. Прогресивні системи обробітку грунту; за ред. В.П. Гордієнка. Сімферополь, 1998. $272 \mathrm{c}$.

8. Kovalenko A. Increasing aridity climate of southern steppe of Ukraine. Its effects and remedies, 3rd UNCCD Scicntific Conference, 9-12 March 2015, Cancun. Mexico: Book of Abstracts, 2015. P. 293-294.

9. Вожегова Р. А., Коваленко А. М. та ін. Формування систем обробітку грунту в короткоротаційних сівозмінах: науково-методичні рекомендації. Херсон: ВЦ І33, 2015. 18 с.

10. Вожегова Р. А., Коваленко А. М. Зміни клімату в південному регіоні та напрями адаптації землеробства до них. Посібник украӥнського хлібороба «Адаптивне землеробство». Київ: ТОВ «АКАДЕМПРЕС», 2013. Том 1. С. 189-190.

11. Тимошенко Г. З., Коваленко А. М., Новохижній М. В. Вплив різних способів основного обробітку грунту на урожайність ячменю ярого. Зрошуване землеробство: міжвідомчий тематичний науковий збірник. Херсон: Грінь Д.С., 2015. Вип. 64. С. 114-116.

12. Малярчук М. П., Вожегова Р. А., Марковська О. С. Формування систем основного обробітку грунту в агробіоценозах на меліорованих землях південної посушливої та сухо степової грунтовоекологічних підзон України: навчальний посібник. Херсон: Айлант, 2012. $180 \mathrm{c}$.

Information about the author: Maliarchuk M. P., Doctor of Agricultural Science, Senior Researcher, Chief Researcher, Institute of Irrigated Agriculture of the National Academy of Agrarian Sciences of Ukraine Kherson, Naddniprianske, 73483, Ukraine 